\title{
Kierunki zmian w systemach emerytalnych w początku XXI wieku
}

\section{Wstęp}

C początkiem wieku XXI nastąpiły liczne zmiany w systemach emerytalOnych w poszczególnych krajach. Na zmiany te miał wpływ światowy kryzys finansowy rozpoczęty upadkiem banku Lehman Brothers w roku 2008, ale i uprzednio zaznaczone przekształcenia w strukturze demograficznej ludności wielu krajów, jak i dotyczące ogólnej sytuacji ekonomicznej i wzrostu gospodarczego. Istotny wpływ wywarły również czynniki międzynarodowe - z powodu ryzyka rynków finansowych, bardzo wysokich kosztów przejścia na system kapitałowy w krajach o rozbudowanym systemie opartym na repartycji i trudności społecznych, ekonomicznych, jak i organizacyjnych związanych z przeprowadzeniem zmian.

\section{Europa Zachodnia}

W krajach europejskich zaznaczyła się początkowo tendencja do ograniczenia przechodzenia na emeryturę we wcześniejszym wieku niż ogólnie przyjęty wiek emerytalny zarówno ze względów finansowych, jak i zatrudnieniowych, następnie zapoczątkowano przechodzenie z systemu określonego świadczenia na system określonej składki i z kolei podniesienie w przyszłości wieku emerytalnego do 67 lat dla mężczyzn i kobiet.

1. Faktyczna dezaktywizacja zawodowa przed osiągnięciem wieku emerytalnego następowała różnymi drogami. W Niemczech w 1972 r. wprowadzono uelastycznienie wieku emerytalnego dla długo ubezpieczonych od ukończenia 63 lat życia i dla rencistów od 60 lat. Poprzednio już dla bezrobotnych wiek ten został obniżony do 60 lat, co powodowało, że mężczyźni, którzy stali się bezrobotnymi w wieku 58 lat uzyskiwali

\footnotetext{
* Prof. zw. dr hab., Wydział Zarządzania Uniwersytetu Warszawskiego.
} 
zasiłki dla bezrobotnych, aby osiągając 60 lat skorzystać z pełnej emerytury o pięć lat wcześniej. W Wielkiej Brytanii przedsiębiorstwa, podobnie jak w Stanach Zjednoczonych, ustalały w zakładowych systemach emerytalnych niższy wiek uprawniający do świadczeń, aby wymusić dobrowolną rezygnację z pracy starszych pracowników, stosowano również ułatwienia $w$ uzyskiwaniu rent inwalidzkich tak, że liczba ich uległa w tym kraju potrojeniu w okresie 1976-1995. W Szwecji w latach 1970-1991 bezrobotny w wieku 58 lat otrzymywał rentę inwalidzką bez badania lekarskiego do czasu uzyskania emerytury. We Włoszech po 35 latach zatrudnienia można było, bez względu na wiek, przejść na emeryturę. We Francji wobec obniżenia w roku 1983 wieku emerytalnego do 60 lat problem wcześniejszych świadczeń przeniósł się poniżej tej granicy.

$Z$ jednej strony bezrobocie prowadzi do rozbudowy świadczeń ubezpieczenia i pomocy społecznej, z drugiej motywuje do dezaktywizacji. Dopiero około połowy lat dziewięćdziesiątych ubiegłego wieku poszczególne państwa przystąpiły do ograniczania świadczeń na rzecz polityki aktywizacji zawodowej ludności w starszym wieku. Niemniej w 1999 r. w krajach Unii (15) aktywność zawodowa mężczyzn w wieku 55-64 lata wynosiła tylko 48,3\% (Belgia 35,1\%, Francja 38,9\%, Włochy 40\%, Austria $41,6 \%$ Niemcy $48,0 \%$, Wielka Brytania 59,4\%), podczas gdy w Stanach Zjednoczonych wskaźnik ten wynosił $66,1 \%$ a w Japonii $79,5 \%{ }^{1}$. Problemem więc pozostawało nie tyle podwyższanie wieku emerytalnego, ile aktywizacja do tego wieku. W związku z tym w 2000 r. w Lizbonie Unia Europejska podjęła program aktywizacji zawodowej ludności w wieku powyżej 50 lat. Realizacja tego programu jest jednak trudniejsza.

Składką ubezpieczeniową i podatkiem finansowano świadczenia dla bezrobotnych. We Francji tego rodzaju dodatkowy, drugi stopień zabezpieczenia rozbudowano już w 1984 r. pod nazwą specjalnego zasiłku solidarnościowego. W Niemczech w 2005 r. dokonano zharmonizowania wsparcia zasiłkowego przez biura pracy z pomocą społeczną gmin. W Szwecji w ostatniej dekadzie wieku XX wprowadzono szereg zmian ograniczających wypłacanie zasiłku dla bezrobotnych, w szczególności od 1996 r. prawo do zasiłku zostało zawieszone na okres dziewięciu tygodni $\mathrm{w}$ razie zaprzestania pracy bez uzasadnionej przyczyny, który to warunek do owego czasu nie był w ogóle wymagany.

Łatwość uzyskania w Europie świadczeń ilustruje odsetek mężczyzn w wieku 59 lat pobierających w 2000 r. renty inwalidzkie lub zasiłki dla bezrobotnych: 21\% Francja, 24\% Szwecja, 27\% Holandia, 33\% Wielka Brytania, 37\% Niemcy, gdy w Stanach Zjednoczonych, podobnie jak

${ }^{1}$ T. Maltby i in. (eds), Ageing and the Transition to Retirement, Aldershot 2004. 
w Japonii, było to $12 \%{ }^{2}$. Wobec tego zaznaczyła się tendencja do ograniczania tych świadczeń. W Niemczech w 2004 r. skrócono okres wypłaty zasiłku dla długotrwale bezrobotnych, a w 2006 r. wprowadzono obowiązek podjęcia pierwszej proponowanej pracy pod rygorem zmniejszenia zasiłku, a przy dalszej odmowie jego utratę. W krajach skandynawskich, Holandii i Wielkiej Brytanii pewne ograniczenia wystąpiły już wcześniej. Dało się zauważyć odejście od rent inwalidzkich jako środka łagodzenia bezrobocia. W Stanach Zjednoczonych, wobec restrykcyjnego systemu ubezpieczenia na wypadek bezrobocia, już od 1996 r. podjęto politykę aktywizacji zawodowej pobierających zapomogi z pomocy społecznej. Ogólnie starano się podjąć politykę aktywizacji zawodowej wobec zmian przynoszących przez globalizację gospodarki i rodzącą się konkurencję ze strony krajów rozwijających się, przy spadku znaczenia i roli związków zawodowych.

2. Wprowadzenie systemu określonej składki - rozwiązania stosowanego w prywatnym ubezpieczeniu osobowym na dożycie - w miejsce określonego świadczenia ustalono przyszłościowo w 1995 r. we Włoszech, w 1996 r. na Łotwie, w 1999 r. w Polsce i Szwecji, poza Europą zaś w 1997 r. w Kazachstanie, w 1999 r. w Brazylii, w roku 2000 w Mongolii.

3. Wiek emerytalny podniesiono, z perspektywą nawet do 2040 r., dla mężczyzn i kobiet do 67 lat: w Niemczech, Holandii, Wielkiej Brytanii, Francji (dla pełnej emerytury), Hiszpanii, Szwecji (powrót do stanu sprzed 1976 r.), Polsce oraz do 68 lat w Finlandii, Irlandii (obniżono z 70 do 65 lat dopiero w 1961 r.) i we Włoszech. Norwegia tradycyjnie utrzymywała 67 lat. W krajach posocjalistycznych podniesienie wieku emerytalnego następuje wolniej, ponieważ poziom ten był tu niższy: 60 lat dla mężczyzn i 55 dla kobiet, a Polska i NRD z wymiarem 65 i 60 lat były wyjątkiem.

Znaczniejszą reformę przeprowadziła Holandia w 2006 r., dokonując daleko idących zmian w anglosaskim duchu liberalnym. Wprowadziła pierwszy filar finansowany redystrybucyjnie, o zryczałtowanym świadczeniu dla wszystkich (pracowników, w tym służby cywilnej, samodzielnie pracujących i rolników) w pełnej wysokości w wieku 65 lat przy odliczeniu $2 \%$ za każdy rok wyjazdu lub pracy za granica, bez możliwości wcześniejszego uzyskania świadczenia. Składka jest pobierana od dochodu przez pracodawcę i przekazywana urzędom skarbowym, osoby nie posiadające dochodu składki nie opłacają. Drugi filar stanowią zakładowe systemy emerytalne o podobnie obowiązkowej przynależności, tworzone na podstawie układów zbiorowych pracy. Środki tych systemów

${ }^{2}$ V. Galasso, The Political Future of Social Security in Ageing Societies, Cambridge (USA) 2006; Ch. Prinz (ed.), European Disability Pension Policies 11 Country Trends 1970-2002, Aldershot 2003. 
podlegają lokacie albo w prywatnym zakładzie ubezpieczeniowym, albo $\mathrm{w}$ funduszu utworzonym przez pracodawcę. Składki pozostają zwolnione $\mathrm{z}$ podatku, a opodatkowaniu podlega świadczenie ${ }^{3}$.

W Niemczech zmiany następowały na skutek wprowadzania kolejnych ustaw, popierających rozwój emerytur zakładowych i indywidualnych. W 2002 r. wprowadzono nowy filar - dodatkowe ubezpieczenie prywatne, ale obowiązkowe, subsydiowane przez państwo, podobnie jak w Wielkiej Brytanii ${ }^{4}$. Ustawa z 2004 r. wprowadziła nowe obliczenie wysokości świadczenia poprzez zastosowanie wskaźnika zależności - stosunku liczby emerytów do łącznej liczby płacących składkę i bezrobotnych - przez co nastąpiło zbliżenie do systemu określonej składki ${ }^{5}$. We Francji, mimo licznych strajków, manifestacji i pochodów, w których brali udział także studenci i uczniowie, w 2010 r. udało się podnieść ustawowo wiek emerytalny dla wszystkich ubezpieczonych z 60 do 62 lat zarówno dla mężczyzn, jak i dla kobiet. Faktyczny wiek emerytalny wynosił dla mężczyzn 58,5, a dla kobiet 59 lat. Nastąpiło również przedłużenie wymaganego okresu zatrudnienia do pełnej emerytury do 40 lat $^{6}$.

\section{Kraje Europy Środkowo-Wschodniej}

Do realizacji systemu podobnego do wprowadzonego na Węgrzech w 1998 r. i w Polsce w 1999 r. przystąpiła w 2000 r. Łotwa, a rok później Estonia, w dwa zaś lata później Litwa i Bułgaria, w 2004 r. Słowacja. Rumunia obowiązkowy II filar kapitałowy wprowadziła w 2008 r., a Mołdowa poprzestała na usprawnianiu funkcjonującego systemu. W krajach byłej Jugosławii zmiany następowały w podobnym kierunku od $2002 \mathrm{r}$. w Chorwacji, w roku 2003 w Macedonii (ze względu na liczbę ludności powołano tylko dwa fundusze w II obowiązkowym filarze), w 2004 w Czarnogórze, w Bośni i Hercegowinie ustawę o reformie przyjęto w 2008 r., Serbia ze względu na koszt wstrzymała się natomiast z przeprowadzeniem reformy (2008 r.). W krajach tych koncentrowano się na podniesieniu odziedziczonego po poprzednim ustroju niskiego wieku emerytalnego 60/55 lat stopniowo do wieku 65 lat, także dla kobiet, chociaż wolniej, oraz poparcia rozwoju dobrowolnych ubezpieczeń na dożycie odgrywającego rolę III filaru. Tym samym model systemu emerytalnego zalecony przez Bank Światowy (z niewielkimi odmianami) stał się w Europie Środkowo-

${ }^{3}$ M. Rein, W. Schmal (eds), Rethinking the Welfare State. The political Economy of Pension Reform, Cheltenham 2004.

${ }^{4}$ T. Maltby i in. (eds), Ageing and the Transition...

${ }^{5}$ R. Holzman, E. Palmer (eds), Pension Reform. Issues and Prospects for Non-Financial Defined Contribution (NDC) Schemes, Washington 2006.

${ }^{6}$ B. Palier, La réforme des retraites, Paris 2010. 
-Wschodniej dominujący, tworząc obok Ameryki Łacińskiej dwa wielkie obszary jego zastosowania w świecie. Natomiast Słowenia, podobnie jak Czechy, dwa państwa tego regionu nie zadłużone i nie ustępujące krajom zachodnim ani pod względem gospodarczym, ani społecznym (umieralności niemowląt, długości życia) nie przystąpiły do tak radykalnych reform i śladem Niemiec postawiły na rozbudowę III filaru.

Światowy kryzys finansowy oddziałał negatywnie na funkcjonowanie tak zorganizowanych systemów emerytalnych w tych krajach, w szczególności na poziom aktywów w otwartych funduszach emerytalnych. Spowodowało to ich zmiany. Na Węgrzech w drodze faktycznej fundusze te uległy likwidacji w 2011 r. Ich uczestnicy, wobec zapowiedzi utraty emerytury z I filaru w przypadku pozostania w otwartym funduszu, wycofali się z nich i wrócili do pierwszego filaru, ograniczając się do niego. Próby likwidacji otwartych funduszy w Bułgarii i Słowacji spotkały się ze sprzeciwem Międzynarodowego Funduszu Walutowego. Kraje tego regionu Europy obniżyły natomiast wysokość składki do funduszy, względnie ich wpłatę zawiesiły.

W Rosji dekret o niepaństwowych funduszach emerytalnych wydano już w 1992 r. Powstało ponad 200 rozdrobnionych funduszy o dobrowolnej składce i silnej koncentracji. Ustawy z $2001 \mathrm{r}$. wprowadziły system emerytalny bazowy, o określonej składce, i drugi filar kapitałowy w funduszach państwowych, ale zarządzanych prywatnie. W 2003 r. w systemie wprowadzono zmiany. Poziom produktu krajowego brutto z 1989 r. osiągnięto dopiero po dwunastu latach. Zmian tych dokonywano w sprzyjającej sytuacji gospodarczej, wobec wzrostu światowych cen eksportowanej ropy naftowej i gazu, co wpływało na regularność wypłat wynagrodzeń i emerytur. Korzystna sytuacja uległa jednak zmianie wobec spadku tych cen w 2008 r. Sytuacja gospodarcza na Ukrainie ciaggle pozostaje trudna, ponieważ do 2002 r. nie osiągnięto jeszcze nawet połowy wielkości produktu krajowego brutto z 1989 r. przy wysokiej inflacji, oficjalnym bardzo niskim wskaźniku bezrobocia i szacowaniu szarej strefy na 50-70\% tego produktu. W 2001 r. wydano ustawę o nadzorze nad powstającymi dobrowolnymi funduszami prywatnymi, następnie w 2003 r. ustawę o systemie emerytalnym z drugim filarem kapitałowym, ale z wejściem w życie przy zaistnieniu odpowiednich warunków ekonomicznych. Natomiast w dotychczasowym systemie przeliczono emerytury na nowych zasadach składek, wydłużono okres niezbędny dla nabycia uprawnień, ograniczono waloryzację, pozostawiając wiek 60 i 55 lat. Światowy kryzys finansowy 2008 r. dotknął w szczególności Ukrainę, utrudniając reformy. Fundusze w Rosji i na Ukrainie różnią się od węgierskich czy polskich. Zakładało je państwo, które zawierało umowy z podmiotami prywatnymi o ich zarządzanie ${ }^{7}$.

7 P. Kurowski, Rozwój funduszy emerytalnych w wybranych krajach Europy Środkowo-Wschodniej. Warunki startu i funkcjonowania, Warszawa 2006. 
Z kolei w Kazachstanie, silnie preferowanym przez Bank Światowy, wprowadzono w 1998 r. system w pełni oparty na kapitalizacji, wzorem reformy w Chile z $1981 \mathrm{r}$.

\section{Ameryka Łacińska}

W ciągu lat 1993-2003 aż dziesięć krajów Ameryki Łacińskiej przeprowadziło reformy emerytalne oparte na systemie kapitalizacji, wzorując je na modelu wprowadzonym w Chile w $1981 \mathrm{r}$. Dla lepszej orientacji należy wziąć również pod uwagę fakt, że według szacunków na przełomie XX i XXI w. w krajach Ameryki Łacińskiej wśród ludności zawodowo aktywnej poza rolnictwem (z wyjątkiem Urugwaju) aż blisko połowa pracowała w sektorze nieformalnym, jednocześnie w tych państwach działalność pomocy społecznej była słabo rozwinięta ${ }^{8}$.

Jednakże w Chile po dwudziestu kilku latach funkcjonowania nowego systemu wystąpiły poważne trudności. Składkę faktycznie uiszczało zaledwie około 50\% uczestników. Powodem tego, podobnie jak w innych krajach Ameryki Łacińskiej, była szczupłość sektora zatrudnienia formalnego, jedynie dorywcze podejmowanie pracy, jak też częste zaprzestanie opłacania składek po osiągnięciu okresu uprawniającego do gwarantowanego świadczenia minimalnego. W efekcie dla połowy przechodzących na emeryturę stopa zwrotu kształtowała się poniżej 40\%, co w szczególności dotyczyło kobiet, a tylko dla $20 \%$ powyżej wysokości minimalnej, przy 55\% nie uzyskujących takiego uprawnienia, natomiast kwota wypłat świadczeń minimalnych przekroczyła $4 \%$ produktu krajowego brutto finansowanego z budżetu państwa. W tym stanie Międzynarodowa Organizacja Pracy wszczęła działania na rzecz rozwinięcia w tym systemie elementów opartych na zasadzie solidarności społecznej promowanej przez nią przeciwnej jednostronności indywidualnego oszczędzania preferowanego przez Bank Światowy. W wyniku tego doszło do istotnej reformy w 2008 r. Wprowadzono świadczenia dla najbiedniejszych, nie posiadających oszczędności, w stałej wysokości, poprzez odpowiednie dopełnienie składek do ustalonej wysokości, subsydia do 24 pierwszych opłacanych składek dla pracowników w wieku 18-35 lat, obowiązek ubezpieczenia dla samozatrudnionych, kompensatę dla kobiet za okresy nieskładkowe, położono nacisk na kontrolę i rozwijanie odpowiednich bodźców. Odrębne pozostały nadal systemy dla wojska i policji. W 2008 r. w ośmiu funduszach, jakie funkcjonowały, wkłady uczestników spadły o około dziewięć lat opłacania składek, co wiązało się z ogólnoświatowym kryzysem finan-

${ }^{8}$ K. Kołodziejczyk, Systemy emerytalne w Ameryce Łacińskiej. Od repartycji do kapitalizacji, Poznań 2004. 
sowym, niemniej koszty administracyjne sięgają w nich 20\%. Jednakże według doniesień w okresie 1987-2006 liczba gospodarstw domowych funkcjonujących w ubóstwie zmalała z 45 do 13\%, co wiąże się ze skuteczną interwencją państwa $\mathrm{w}$ dziedzinie polityki społecznej (pomoc dla rodzin, emerytów, bezrobotnych, programy edukacji i zdrowia) oraz wzrostem ekonomicznym ${ }^{9}$. Niemniej, stosownie do rozpoznania Międzynarodowej Organizacji Pracy w Chile, poza ubezpieczeniem emerytalnym pozostaje nadal $40 \%$ ludności, składkę regularnie opłaca tylko 11\% pracowników, a składki ponad połowy pracowników nie gwarantują emerytury minimalnej ${ }^{10}$.

Argentyna wprowadziła w 1994 r. zalecony przez Bank Światowy model kapitałowy, z kolei przeniesiony do Europy Środkowo-Wschodniej (Węgry 1998 r., Polska 1999 r., następnie inne kraje tego regionu). Przez szereg lat nie podnoszono wysokości emerytury minimalnej. Później jednak, wobec kryzysowej sytuacji gospodarczej i bezrobocia, zaczęto to robić, tak że w 2007 r. emerytura minimalna osiągnęła 90\% emerytury przeciętnej, a odsetek pobierających ją wśród ogółu emerytów wzrósł do 70\%. Jednocześnie wszelkie wydatki emerytalne sięgnęły ponad $8 \%$ produktu krajowego brutto. W 2008 r. przeprowadzono radykalne zmiany. Starszych ubezpieczonych, którzy nie zgromadzili w funduszach określonej kwoty, przeniesiono z powrotem do systemu repartycyjnego, nowi pracownicy zostali objęci tymże systemem, chyba że wybrali uczestnictwo w funduszach. Nauczycielom, pracownikom sądów, służby dyplomatycznej, nauki przywrócono systemy repartycyjne o zdefiniowanym świadczeniu. Ogółem przeniesiono do systemu repartycyjnego 21\% uczestników funduszy. W końcu tego roku, wskutek kryzysu finansowego, dokonano nacjonalizacji funduszy. Tym samym nastąpiło wycofanie się z poprzednio wprowadzonego systemu. Podobnie z systemu takiego, wprowadzonego w 1997 r., wycofała się w roku 2008 Boliwia.

W przeciwieństwie do innych krajów Ameryki Łacińskiej Brazylia nie przeprowadziła tak radykalnych zmian. Reformom nie sprzyjała sytuacja polityczna i finansowa tego państwa oraz wysoki koszt ich przeprowadzenia. Korzystna struktura demograficzna, zwiększenia się ludności w wieku aktywności zawodowej do 2030 r., oddala proces starzenia się na dalsze lata. Natomiast w przypadku funkcjonującego systemu wysokie są koszty administracyjne, sięgające 6\% wpływów, niski jest, podobnie jak w innych krajach Ameryki Łacińskiej, odsetek opłacających składkę, wynoszący zaledwie 45\% w 1999 r., co wynika z bezrobocia i dorywczego zatrudnienia,

9 Z. Czepulis-Rutkowska, Reformy emerytalne jako przyszłość obowiązkowych systemów kapitałowych?, „Ubezpieczenie Społeczne. Teoria i Praktyka” 2009, nr 5; B.E. Kritzer, Chile's next generation pension Reform, „Social Security Bulletin” 2008, No 2.

10 Social Security and Rule of Law, ILC 100 ${ }^{\text {th }}$ session 2011, Report III (Part 18). 
obciążeniem jest również deficytowy odrębny system dla funkcjonariuszy państwowych (cywilnych i wojskowych) przyczyniający się do braku zrównoważenia budżetu państwa ${ }^{11}$.

\section{Ameryka Północna}

Należy zaznaczyć, że system emerytalny w Stanach Zjednoczonych Ameryki nie jest kwalifikowany jako system ubezpieczeniowy (Bismarcka), ale jako system Beveridge'a ${ }^{12}$, czyli zaopatrzenia. Podniesienie wieku emerytalnego do 67 lat w roku 2027 zostało ustalone ustawą już w 1983 r., to znaczy z wyprzedzeniem na okres pracy jednego pokolenia. Głównym motywem tego posunięcia były przewidywania dotyczące potrzeb odnoszących się do stanu zatrudnienia. Niemniej jeszcze w 2001 r. 54\% mężczyzn i 58\% kobiet przechodziło na emeryturę w wieku 62 lat. Emeryturę otrzymywało 90\% Amerykanów w wieku ponad 65 lat, dla jednej piątej z nich stanowiła ona jedyne źródło dochodu. Bieda w 1993 r. dotyczyła $10 \%$ emerytów o okresie zatrudnienia 41 i więcej lat, natomiast wśród pracujących 20 lat i mniej $48 \%{ }^{13}$. Wcześniejszemu przechodzeniu na emeryturę sprzyjały zakładowe systemy emerytalne, tworzone między innymi dla łatwiejszego pozbywania się starszych pracowników.

W przeciwieństwie do Australii i Nowej Zelandii Kanada poszła drogą zbliżoną do rozwiązań angielskich. Zapewnia wszystkim świadczenie zaopatrzeniowe, finansowane z podatków, po ukończeniu 65 lat życia, w wysokości zryczałtowanej, ale zróżnicowanej w zależności od okresu zamieszkania w Kanadzie i skorygowanej w stosunku do osób nie posiadających innego dochodu oraz przekraczających określony łączny jego pułap. Drugi filar stanowi ubezpieczenie opłacane składką w wysokości 9,9\% od wynagrodzenia, płaconą po połowie przez pracowników i pracodawców. Zapewnia ono emeryturę $\mathrm{w}$ wysokości $25 \%$ przeciętnych miesięcznych zwaloryzowanych zarobków uzyskanych w okresie opłacania składki, licząc od 1966 r. Z tego ubezpieczenia są wypłacane również renty inwalidzkie i rodzinne. Ubezpieczenie rozporządza nadwyżkami dochodu, powiększającymi rezerwę finansowa, z której zysk częściowo pozostaje wykorzystany na świadczenia ${ }^{14}$. Korzystna sytuacja wspomnianego ubezpieczenia wynika ze szczególnych okoliczności, które obrazują następujące wskaźniki: 20\% ludności urodziło się za granica, 3,6\% wynosi przyrost naturalny, $13 \%$ ludności przekroczyło 65 lat, przy przeciętnej życia liczącej 80,2 roku i wskaźniku aktywności zawodowej wynoszącym 67,6\% (2007 r.).

${ }^{11}$ E. Overbye, P.A. Kemp(eds), Pensions Challenges and Reforms, Aldershot 2004.

12 D. Blake, Pension economics, Chichester 2006.

13 P.A. Diamond, P.R. Orszag, Saving Social Security, Washington 2005.

${ }^{14}$ S. Pieńkowska, Kanadyjski system ubezpieczeń emerytalnych, "Polityka Społeczna” 2005, nr 10. 


\section{Azja i Afryka}

W krajach Azji Południowej i Afryki Subsacharyjskiej poza jakimkolwiek systemem ubezpieczenia społecznego pozostaje $90 \%$ ludności. W krajach tych rozwój gospodarczy utrudnia zatrudnienie nieformalne, które - poza rolnictwem - jest oceniane przez Międzynarodową Organizację Pracy na 65\% w Azji, 51\% w Ameryce Łacińskiej, 48\% w Afryce Północnej i 72\% w Afryce Subsacharyjskiej ${ }^{15}$.

W krajach Azji Południowo-Wschodniej korzystanie z form zabezpieczenia społecznego, poza wyżej uprzemysłowioną i zurbanizowaną Koreą Południowa, ogranicza się do funkcjonariuszy państwowych i ewentualnie pracowników wielkich zakładów. Azjatycki kryzys gospodarczy lat 1997-1999 opóźnił ogólny rozwój, dotykając zwłaszcza Indonezji i Tajlandii $^{16}$. W Chinach przedsiębiorstwa państwowe realizowały pewne świadczenia socjalne dla swych pracowników w miastach, w tym emerytalne po 20 latach zatrudnienia. Na fali reform w 1997 r. ujednolicono w ramach prowincji składkę i wypłatę, wprowadzono system trzyfilarowy: pierwszy repartycyjny, drugi kapitałowy i trzeci dobrowolny prywatny. W roku 2002 mniej niż połowa pracowników w miastach została objęta tym systemem. W rok później liczba opłacających składkę emerytalną osiągnęła ponad $100 \mathrm{mln}$. Podjęta od 1981 r. polityka ,jednego dziecka w rodzinie” wywołała niekorzystną sytuację demograficzną w kontekście ubezpieczenia. Udział ludności liczącej ponad 60 lat życia sięga w Chinach już ponad 13\% i przewiduje się dalszy i szybki jego wzrost. Od 2004 r. przyjęto kierunek na rozwój ubezpieczenia społecznego ${ }^{17}$.

O sytuacji zabezpieczenia na starość, a raczej jego braku, świadczą dane o procencie ludności starej zamieszkałej około 2000 r. wraz z dziećmi: ponad 80\% Indie i Chiny, nieco mniej Korea Południowa, Tajlandia, Indonezja, około 60\% Japonia, Chile, Urugwaj, 40\% Włochy, ponad 20\% Argentyna, Austria, poniżej 20\% kraje Europy Zachodniej i Stany Zjednoczone Ameryki, najmniej jest jej w krajach skandynawskich i Holandii. Zestawienie to ilustruje, choć w sposób zgoła ogólny i tylko kierunkowy, stan rozwoju form zabezpieczenia społecznego - od jego braku do najwyższych form ${ }^{18}$.

Natomiast sytuacja w Japonii, zaliczanej do największych potęg gospodarczych i przemysłowych świata, przedstawia się inaczej. System

${ }^{15}$ Employment and social Protection in the Demographic Content, Genewa 2010.

${ }_{16}$ J. Midgley, T. Kwong-Leung (eds), Social Policy in East Asia. The Role of Social Security, London 2010.

${ }_{17} \mathrm{Ka}$ Lin, O. Kangas, L'élaboration de la politique sociale et sa base institutionelle: transition du système chinois de sécurité sociale, "Revue internationale de sécurité sociale" 2006, nº 2.

${ }_{18}$ D.A. Robalino (ed.), Pensions in the Middle East and North Africa. Time of Change, Washington 2005. 
emerytalny został wprowadzony w 1942 r. w celu finansowania wojny. Można w tym miejscu przypomnieć, że w Polsce wprowadzony w $1933 \mathrm{r}$. system emerytalny dla robotników w okresie do wybuchu wojny, wobec braku wypłat przy pobieraniu składek, służył finansowaniu wielkich inwestycji państwowych. Ubezpieczenie społeczne przejściowo, jak widać, może służyć różnym celom. W 1952 r. zmniejszono podatek przedsiębiorstwom wypłacającym swym pracownikom odprawy emerytalne, 90\% wielkich przedsiębiorstw, zatrudniających powyżej tysiąca pracowników, a obejmujących $30 \%$ ogółu pracowników, płaciło bowiem takie odprawy ryczałtowe z rezerwy księgowej lub z funduszu. Pod presją postępującego w szybkim tempie i przewidywanego starzenia się ludności przystąpiono do zmian. Grupa ludności liczącej ponad 65 lat osiągnęła 20\% już w 2005 r., a do 2033 r. ma sięgnąć 30\%, przy szczycie liczby ludności przypadającym w 2006 r. Podniesiono wiek emerytalny do 65 lat docelowo od 2013 r., jednakowo dla mężczyzn i kobiet (z 60 i 58 lat). Ustawy z 2001 r. wprowadziły pierwszy filar ryczałtowy i drugi określonego świadczenia, redystrybucyjny po 40 latach składkowych, z możliwością przejścia na emeryturę w wieku 60-70 lat. W przypadku pobierania przez mężczyznę pełnej emerytury otrzymuje on ryczałtowy dodatek na żonę. W 2004 r. podniesiono składkę i obniżono wyliczenie wysokości świadczeń. Wprowadzono też ubezpieczenie pielęgnacyjne dla osób starszych ${ }^{19}$.

Jak wynika $\mathrm{z}$ tego przedstawienia, początek wieku XXI obfitował w liczne zmiany systemów emerytalnych spowodowane przemianami społeczno-gospodarczymi.

\section{Bibliografia}

Blake D., Pension Economics, Chichester 2006.

Czepulis-Rutkowska Z., Reformy emerytalne. Jaka przyszłość obowiazkowych systemów kapitałowych?, „Ubezpieczenie Społeczne. Teoria i Praktyka” 2009, nr 5.

Diamond P.A., Orszag P.R., Saving Social Security, Washington 2005.

Employment and social protection in the New Demographic Context, Genewa 2010.

Fornero E., Sestio P. (eds), Pension Systems. Beyond Mandatory Retirement, Cheltenham 2005. Galasso V., The Political Future of Social Security in Ageing Societies, Cambridge (USA) 2006.

Holzmann R., Palmer E. (eds), Pension Reform. Issues and Prospects for Non-Financial Defined Contribution (NDC) Schemes, Washington 2006.

Ka Lin, O. Kangas, L'élaboration de la politique sociale et sa base institutionnelle : transition du système chinois de sécurité sociale, "Revue internationale de sécurité sociale” 2006, nº 2.

Kritzer B.E., Chile's next generation pension reform, „Social Security Bulletin” 2008, No 2.

Kurowski P., Rozwój funduszy emerytalnych w wybranych krajach Europy Środkowo-Wschodniej. Warunki startu i funkcjonowania, Warszawa 2006.

Maltby T. i in. (eds), Ageing and the Transition to Retirement, Aldershot 2004.

${ }^{19}$ M. Rein, Rethinking the Welfare State...; R. Holzman, E. Palmer (eds), Pension Reform... 
Kierunki zmian w systemach emerytalnych w początku XXI wieku

Midgley J., Kwong-Leung T. (eds), Social Policy in East Asia. The Role of Social Security, London 2010.

Overbye E., Kemp P.A. (eds), Pensions Challenges and Reforms, Aldershot 2004.

Palier B., La reforme des retraites, Paris 2010.

Pieńkowska S., Kanadyjski system ubezpieczeń emerytalnych, „Polityka Społeczna” 2005, nr 10.

Prinz Ch. (ed.), European Disability Pension Policies. 11 Country Trends 1970-2002, Aldershot 2003.

Rein M., Schmal W. (eds), Rethinking the Welfare State. The political Economy of Pension Reform, Cheltenham 2004.

Robalino D.A. (ed.), Pensions in the Middle East and North Africa. Time for Change, Washington 2005.

Sigg R., Behrendl Ch. (eds), La sécurité sociale dans le village global, Berlin 2004.

Social Security and Rule of Law, ILC 100 ${ }^{\text {th }}$ session 2011. Report III (Part 1B).

\section{The Directions of Changes in Pension Systems in the $21^{\text {th }}$ Century}

\section{Summary}

The changes in economy at the beginning of the century have determined the pension systems in the world. The author presents the evolutions to the current state of the pensions in Europe, Latin and North America, Asia and Africa. 